\title{
Global rural value chains and the role of natural disasters in their transformation
}

\author{
Meinhard Breiling ${ }^{1}$ (D)
}

Accepted: 22 January 2021 / Published online: 12 February 2021

(c) The Author(s) 2021

\begin{abstract}
Global rural value chains relate to business activities in non-central locations all over the world. They contain almost all global agricultural production, a major part of global tourism, and minor shares of industry and other services than tourism. Their generated value is more dependent on climate and extreme weather events than what is the case with urban value chains. Concepts of disaster vulnerability and disaster resilience to rural value chains are presented and followed by a system view on global rural value according to four income groups of countries. A different meaning of disasters becomes perceivable for each income group. We come up with four cases of successful in some aspects controversial alterations of global rural value chains: palm oil value chain in ASEAN, the sixth industry in Japan, rural tourism in Asia, and winter tourism in Austria and analyze the impacts of natural disasters in case studies. The business disturbances are manifold, complex, and not entirely adverse. The value at risk in a given location widely depends on the susceptibility of people and environment to a natural disaster, the costs to repair, and possibilities to innovate. Along with economic growth, disasters accelerate transformations in rural value chains and the strive to become more global while contracting in their local extensions.
\end{abstract}

Keywords Rural value chains - Values at risk - Disaster risk management - Climate adaptation $\cdot$ Business innovation $\cdot$ Business resilience $\cdot$ Agriculture $\cdot$ Tourism $\cdot$ Eco-system services

JEL classification $\mathrm{F} 15 \cdot \mathrm{F} 18 \cdot \mathrm{F} 23 \cdot \mathrm{R} 12$

\section{Introduction}

Rural value chains describe interactions of businesses primarily situated in rural areas and generating the rural income. The term "rural" describes environments with lower population and business densities outside urban centers, whereby any geographical unit such as region, country, province, or municipality can be divided into urban and rural. A small urban center is surrounded by a large rural area. An original distinction between urban

Meinhard Breiling

meinhard.breiling@tuwien.ac.at

1 TTL, Technische Universitat Wien, Vienna, Austria 
and rural areas within a country has assumed that urban areas provide a different way of life and usually a higher standard of living than are found in rural areas (UNDESA 2020). In some high and upper middle-income countries where living standards in rural areas became pretty high, this distinction is less pronounced while it still fits to lower middleincome and low-income countries.

The rural value chains stay in close connection and interaction with urban value chains. Their importance could be underestimated due to a relative lower value earned in rural settings. However, rural products like agricultural commodities sum up much higher value if they become fresh food or processed food either directly in rural or in urban areas. Additional value is gained via retail or consuming in restaurants. The initial agricultural value multiplies when industry values and service values are added to the final food value. The desire to take a rest from urban life and long back to the traditional roots in the countryside or nature is motive for people to consume tourism services and products away from urban centers. Many rural locations have switched from agriculture to tourism as main economic activity.

Natural disasters cause widespread damage and losses, and rural value chains are particularly exposed. The rural lead economies, agricultural production amounting for 3.6 percent, and tourism with 3.2 percent (Lock 2020) of global GDP (2018) are in particular climate-dependent income systems (World Bank 2020; UNWTO 2019). The earnings of rural value chains are widely produced outside the built environment in open landscapes exposed to weather and climate variations. Some 91 percent of natural disasters are climate-dependent meteorological disasters and cause about of 77 percent of damages and losses (CRED and UNDRR 2020). The most distant links in the rural value chain-generally the places where raw materials are produced or basic services originate from-are also the most vulnerable to natural disasters. Climate change exacerbates the frequency and intensity of major meteorological disasters in well-observed regions. There is strong evidence for droughts and precipitation extremes and plausible increases to storm events (Coumou and Rahmstorf 2012).

The magnitude or relative share of disaster damage and losses in rural value chains is much higher than in urban value chains. This fact is widely hidden by the much higher absolute value of damage caused in urban value chains. We split global rural value from urban value chains according to four groups of countries, high income, higher middle income, lower middle, and low income based on data for 2018 (World Bank 2019). Disparities between incomes of rural and urban populations resemble differences of low and lower middle-income countries on one side and upper middle and high-income countries on the other sides. Analog to differences between groups of countries and differences between countries within the same group, we find huge differences in rural value chains and divisive developments. Some rural value chains become richer and generate ever more value while others cannot cope with current standards and break down.

Rural values lack behind urban values. Per capita values in rural areas of high-income countries often resemble per capita income values generated in upper and lower middleincome countries. Some rural areas in upper middle-income countries and a large part of rural areas in lower middle-income countries are populated by poor people earning less than 2 USD per day. Under them, we find two billion subsistence farmers not connected to global markets and value chains. They live under the annual threshold of low- income countries with USD 1025 valid in 2018. Lower middle-income countries average amount per capita incomes between USD 1025 to USD 3995, upper middle-income countries range between USD 3996 and USD 12,375 while inhabitants of high-income countries enjoy more than USD 12,375 average per capita income in 2018 (World Bank 2019). 
We conceptualize the role of disasters to value chains by introducing three overlapping circles in Fig. 1. Each circle relates to one basic category and represents people, environment, and values. If there are no people no value is created, no assets are built up in the environment and no damages or losses can be accounted for. People use environment to create values with business activities and building up assets to enhance value formation. Disasters challenge the creation of value as they cause losses in the annual business performance and damage the natural or built environment needed to produce value. People and environment liaise to different levels of susceptibility with regard to disaster shocks. This results in either resilient or vulnerable societies and businesses eager or not to cope with disaster damage and losses or to build up higher levels of resilience.

Low-income societies attempt first to become more people and stronger societies before they can generate higher value. They prosper in a limited radius of interaction. Along time, people gradually build up ever more physical assets like settlements, production and distribution infrastructure, and secure their proper functioning by services. The densest business infrastructures and highest values created are in urban settings. In contrary, businesses in rural areas depend more on natural resources like soil and water as an underlying foundation. The more trade and transport rural businesses can effort the less they depend on local resources. Poor societies or farmers may easily challenge the local resource base of their environments as it is the only perceivable means of profit. While targeting higher incomes and prospering they can decline.

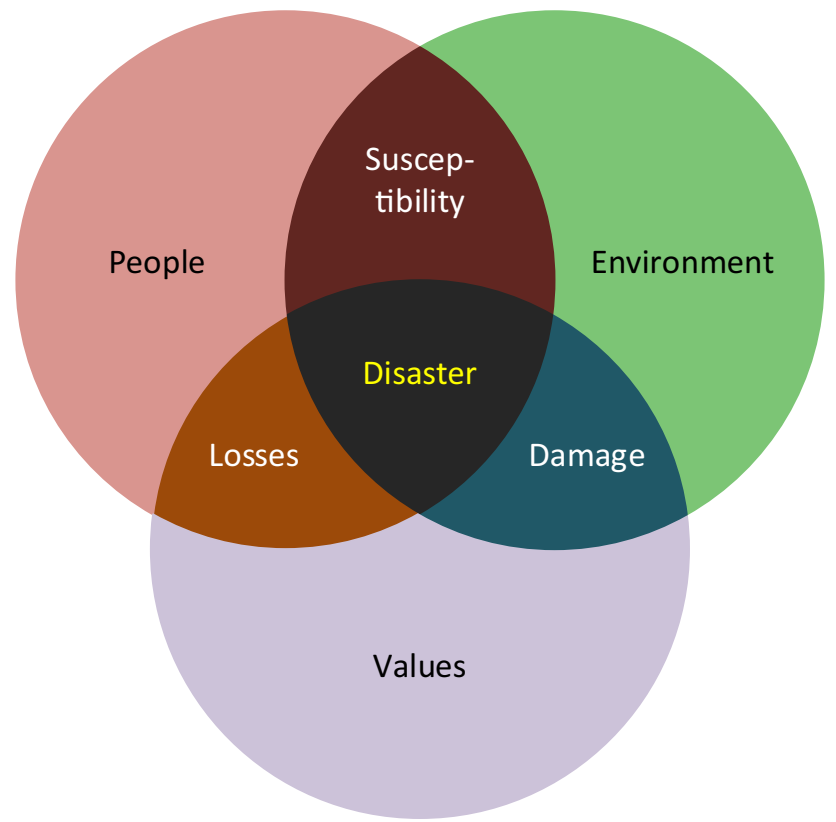

Source: Author

Fig. 1 Values at risk in rural value chains 


\section{Vulnerability in rural value chains to natural disasters}

Businesses at remote ends of rural value chains producing the same products or providing similar services are in a particular difficult situation if value chains start to extend to regional and global scales. Their products and services can now be easily substituted by trade and imported goods. Without a critical or unique business value created the business it at risk to fail even without a disaster. Disasters accelerate processes of decline if the value is not sufficient but they do not cause them. It is the general growth process of global economy which slowly turns smaller scale rural businesses with limited growth potential into pressure of dwindling profitability.

During 2000 to 2019, there were 7348 major recorded natural disaster events or in average 367 disasters a year or at least one major daily disaster in the world. This includes geophysical with 9 percent and climate-related disasters with 91 percent of all events in Emergency Events Database (EM-DAT) not considering biological disasters (epidemics or pandemics like Covid19) taking lives of 1.23 million people or 61,500 death annually (Guha-Sapir 2020).

Weather- and climate-related disasters are taking a heavy toll in rural areas which is in particular difficult to calculate because of under-reporting in low income and lower middleincome countries. The period 2000 to 2019 has seen the number of major floods more than double as compared to the previous 20 years period 1980-1999, from 1389 to 3254, while the incidence of storms grew from 1457 to 2034 (CRED and UNDRR 2020). Floods and storms were the most prevalent events of 6681 climate-related disasters. In 2000-2019, disaster-hit countries also reported direct economic losses valued at US\$2970 billion or 149 billion annually or 0.2 percent of the global value, of which climate-related disasters caused US\$2287 billion or 114 billion each year which is $77 \%$ of the total.

It is expected that climate change will drive the intensity and frequency of meteorological disasters, including extreme temperatures, storms, and floods, in the future (Banholzer et al. 2014). Parts of the historical increase in hazardous events can be credited to better reporting. The increased exposure to events, due to population growth, as well as the increased access to information lead to better reporting of hazardous events (Peduzzi 2005). Despite the high numbers, this is an underestimate of damage and losses due to neglect of damage in the domain of agriculture.

The World Bank estimates global damage with annually USD 330 billion (DRFIP 2019) considerably higher of what is recorded in the CRED database (Guha-Sapir 2020). Wang estimates the average damage of disasters based on available UN data USD 240 billion for the period 2000 to 2019 with the highest value of USD 537 billion in 2011 and the lowest value of USD 93 billion in 2001 (Wang 2020). The corresponding value in GDP was smallest in 2006 with 0.21 percent and highest in 2011 with 0.73 percent, in average over 20 years 0.39 percent direct loss of global value. The indirect loss was considerably higher. The ten countries with the highest direct value loss are the USA with USD 47 billion average annual loss during 1998-2017, followed by China USD 25 billion, Japan USD 19 billion, India and Puerto Rico USD 4 billion, Germany, Italy, and Thailand with annually USD 3 billion, and Mexiko and France with USD 2 billion annually (CRED and UNDRR 2020). The OECD estimated losses for high-income and fast-growing middle-income economies during 2003 and 2023 with USD 1.2 trillion in economic costs from disruptive shocks due to hazards such as storms or floods (OECD, World Bank Group 2019). At the same time, it is stated that not all disaster costs are calculated. Here, primarily insured risk is included. Not all asset categories are included (OECD 2018). Most innovative countries 
like the USA, China, Japan, or Europe that have experienced the highest loss in absolute value do hardly show disruptions in their national value created. Their governments shoulder a significant share of the costs of disasters (OECD, World Bank 2019). In wealthy nations, disasters are the cause to float extra money to affected regions and to compensate, sometimes to even overcompensate, for financial losses. The effects of disasters can thereby have a benign development aspect if businesses are prepared to react in a timely manner.

On a national scale, some countries are particularly hit due to a high share of average disaster loss in their GDP. During 2000-2019 in particular small or highly populated island states like Dominica with 15 percent, Cayman Islands with 9.1, Haiti with 8 or Grenada with 7.8 percent lost enormously of national value due to disasters (CRED and UNDRR 2020). The absolute national loss in value of countries does seldom correlate to the severity of the disaster impact to particular regions and areas that are directly hit. Average national numbers of values do not sufficiently consider the much higher impact of the provoked area within the country. We can only anticipate the gravity by analyzing numbers from disaster hidden but economically weak countries. Due to poor population, little or no value is generated in some rural areas. Poor communities with restricted access to resources are less flexible and more vulnerable in a state of disaster. They incline to overuse their limited assets like agricultural land for immediate short-term needs. In particular disasters of smaller scale are not reported. The methods to assess damage and losses are not harmonized. The value at risk to manageable assets from climate change caused events was calculated with USD 4.2 trillion, in present value terms (The Economist, Intelligent Unit 2016).

In Fig. 2, the share between groups of countries is depicted. Rich countries lose with twothirds of all losses most of value in disasters. Upper middle-income countries have half of all people affected by disasters, while the death rate is highest in low and lower middle-income countries with two- thirds of all fatalities. While the number of fatalities is likely to shrink

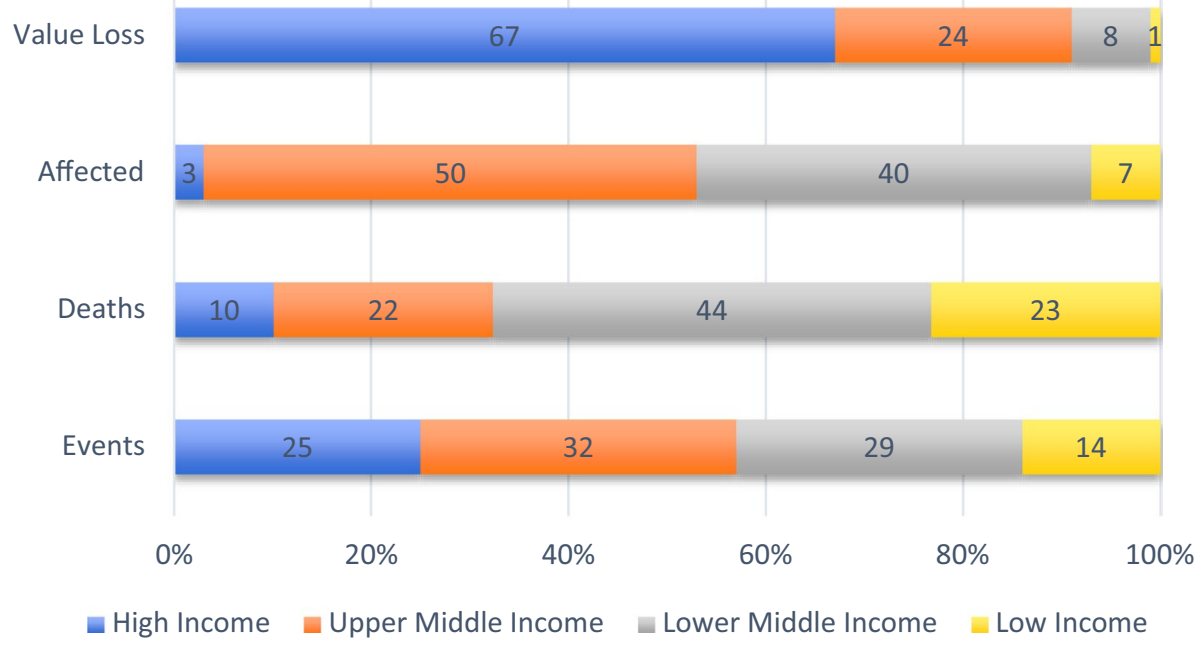

Fig. 2 Percentage of events, deaths, affected and value losses in high, upper middle, lower middle, and lowincome countries during 2000 to 2019 
further-partly due to less people in rural areas living on subsistence agriculture- the value ruined by disasters will multiply in particular with a better economic status of poor people.

Overcoming poverty with decent jobs in rural areas is one of the Millennium Development Goals 2030 (MDGs, United Nations 2015). The potential of rural areas to drive the economy, create productive jobs, improve food security, address environmental and climate change concerns, act as a buffer during crises, and generally to promote sustainable and balanced growth, was widely promoted by the International Labor Organization (ILO 2011). During normal growth periods, people from rural areas are highly attracted by urban areas and migrate to urban centers were more income can be earned. However, in a situation of crisis, the rural hinterlands provide higher degrees of food security and can buffer economic shocks by freely available or inexpensive natural resources. Rural areas hold a buffer reservoir of cheap labor force that can be mobilized during growth period. Workers in agriculture earn only fractions of income what their counterparts in industry or services do. The higher the gap between rural and urban incomes are the more benign workers are to migrate from their traditional settings.

Climate change and climate-related disasters are a threat in particular to rural value chains building on combinations of agriculture and tourism, primarily climate-dependent economic activities that require much more space than other economic sectors. These activities are of lower value than most forms of income in concentrated settings of urban areas. But their value is not dependent on tradeable inputs but on natural resources like climate, water, soil, and landscape in general. In most cases, the agricultural sector does not report damage and losses. A FAO study (2015) identified the share of the agricultural sector in damage and losses reported from 78 climate-related post-disaster need assessments conducted in 48 developing countries between 2003 and 2013 with $25 \%$ of total damage. Crops or livestock show different vulnerabilities to natural disasters. Droughts, with $85 \%$, are the main reason for livestock losses, while tsunamis, with $69 \%$, are the prime reason for damages and losses to fisheries. With $85 \%$, floods are the main reason for crop damage and losses, and storms (89\%) are the dominant cause in the case of forests. A few countries follow individual methodologies to assess the likely damage and losses (Breiling, Anbumozhi 2020). Climate-related disasters can either directly damage assets of rural value chains like soil, water, snow, etc., or cause losses in business operations due to full or partial harvest failures. Hitting agricultural infrastructures like irrigation channels, storage facilities, or machinery can cause additional damages not accounted for in agricultural production. Extreme precipitation leading to floods torrents and avalanches. Heavy storms damage tree stands in forests. Cold or heat periods challenge the health of people and their livestock.

Climate is a local resource asset in a given rural area. Businesses count on firm temperature ranges, regular returning amounts of rainfall or snowfall, a precise length of sunshine hours, modest wind speeds, or particular humidity. Deviations from the expected weather patterns are costly. Agricultural crops have adjusted to particular climate conditions. Cultured forms of sports tourism like skiing depend on certain snow depth layers. Deviations of temperature or precipitation patterns have a strong impact here. The value of land and property seriously declines if the expected products or services cannot be produced in the right amount or quality. In consequence, costly adaptations are required or the price of the land and other assets will go down. 


\section{Strengthening business resilience against disasters}

Rural value depends on people and their economic activities. Disaster events trigger decline when local value chains are disrupted, economic activities cannot be sustained and population starts to move away from their rural homes. Figure 3 depicts in how far disaster risk awareness and disaster risk mitigation can have an impact on values created. The more criteria of risk awareness in place the easier business recovery after disasters can be.

Rural value increases steadily over time. People live from agriculture, forestry, and fishing or the primary sector. Only a smaller portion of the food can be consumed directly, the larger part has to be processed so food can be preserved. If the factory is situated in a rural place this means higher value. The highest value can be obtained when food is consumed in a restaurant. Often the restaurant is out of the rural place in a city nearby, but sometimes a good restaurant can be found in rural settings and thereby the value increases due to the service provided. To get even more value at the local place a local guesthouse can offer overnight stay options and once again the value increases. If there are attractions in the landscape or activities to do, like riding horses or skiing in the mountains again much more value can be obtained in dependence of an available market, either a city nearby or people coming from diverse places all around.

The more complex the rural value chain is, the easier it can be disturbed by a disaster. Clever planning including siting disaster prevention and inundation zones will help to make businesses resilient $f$. e. against floods. Lines with tree providing a defense wall

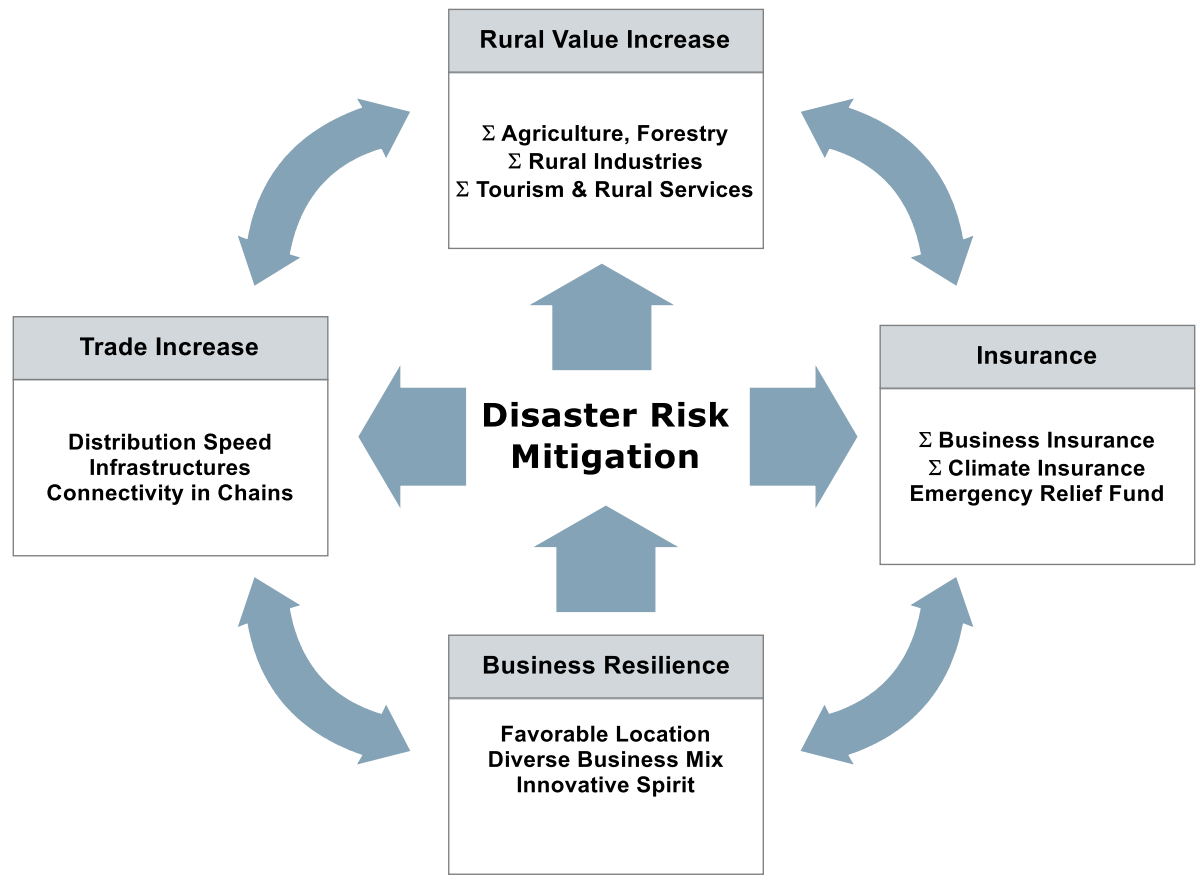

Source: Author

Fig. 3 Disaster risk mitigation in rural value chains 
against wind will slow down wind speeds and attract water with their roots during periods of drought. Diversification of products and services is another mean to make in particular agricultural businesses more resilient against disasters. Having more crops will provide different times of crop maturation. The risk of pests in consequence of extreme weather lessens in extent. Entrepreneurship and experimentation with new kinds of business models and their feasibility to a changed context are another way to improve business and disaster resilience by innovative means.

\section{Trade increase contributing to value chain resilience}

The increase in climate-related disasters coincided with a 30 percent trade increase in agricultural products during 2010 and 2019 (WTO 2020). Due to better distribution and cheaper prices of commodities, the disaster does not lead to a food crisis on the demand side in well-connected urban areas and regions. In particular businesses at the remote beginning of rural supply chains can experience damage and losses by floods or droughts. Beside losing assets for production and losses in harvests they can be easily substituted as business partners by other producers acting on the regional or global market. This is in particular a problem for distant business partners and their competitiveness.

Many solutions that are available today were not ready several decades ago. The basket of responses to threats is considerable larger today than at earlier time mainly due to trade and transport from far away. Agricultural machinery, seeds, fertilizers, pesticides, prefabricated storage facilities, and workforce can be bought from far away if appropriate infrastructure and financial resources are available. While a disaster could have meant hunger and death some time ago, it is not serious today as we have enough possibilities to bring in emergency food supply at any time and to every place on earth. This fact also hides the general bad status of considerable agricultural land a fact that is known since long (Blaikie and Brookfield 1987) and repeatedly considered in UN reports estimating a $20 \%$ of managed and unmanaged land with vegetated surface under persistent declining trends in productivity, mainly as a result of land/water use management practices (UNCCD 2017). To restore this land is currently not a major concern as there is still inexpensive land available. Without the observed intensification of agricultural products trade with annually increase of $2.7 \%$ or $30 \%$ increase over the period 2010 to 2019 (WTO 2020), we would witness many more disasters and conflicts.

The rural areas used for business can decline due to an exploitive depletion of natural resources like soil and water. Long-term resilience is given up for short- term value creation. This is in particular true for the poorest regions of the world and in case of disasters. The number of displacement risk due to natural disasters has quadrupled since the 1970s. This is twice the rate of population growth, meaning that people are twice more likely to be displaced now than they were in the 1970s. Countries in Asia have the highest risk of being displaced. This is due to the fact that there are a large number of vulnerable people in Asia exposed to multiple natural hazards (IDMC 2015). Disasters activate and accelerate migration primarily in low-income countries (Lütz 2013). It depends on internal capacities on how well countries can cope with disasters. Currently, we count 218 million or 3 percent of the global population annually touched by natural disasters, contributing to 65 million forcibly displaced persons and 22 million or 0.3 percent of the global population as refugees.

Disasters make business failures evident: businesses that work under stress already in normal situations cannot continue in a situation of an extra burden. Lacking income to send children to school or to treat family members in hospitals becomes evident. An unknown 
and uncertain future becomes-primarily for holders of small-scale rural businessesmore desirable than to rebuild value in an already challenged business environment at the same location. Wherever made possible by political or economic circumstances, people will migrate. For the remaining rural businesses in place, this situation is adverse even in situations when they are not directly hit. They may lose business partners and have to improvise the ongoing of their own businesses.

\section{Vulnerability related to small-scale business structure and poverty}

Some 560 million small farms with over 2 billion people earn less than two USD a day (Lowder et al. 2016). They cannot participate in larger value chains. Small producers face multiple obstacles in entering local value chains, from high transaction costs to insufficient access to financial resources. Storage facilities or other basic infrastructures need to be established. Increasingly demanding consumer and health standards have to be satisfied. Openness of business processes and traceability is required. Limited access to business services in rural locations makes it additionally difficult for small rural enterprises to become suppliers to larger firms, compete in global value chains, and enter higher value markets (ILO 2011).

Rural areas have valuable agricultural and human resources that remain untapped. Improving value chains and addressing bottlenecks can unleash economic potential and generate employment. Micro, small and medium businesses can cluster in larger units to supply value chains and are major source of employment and income, particularly in rural areas of developing countries. Integrating rural SMEs in value chains can help increase their economic performance and improve working conditions. Small farmer/producerfocused value chains can help rural populations to arise out of subsistence farming and secure the more rewarding gains and income opportunities that well-functioning value chains offer.

Over time small-scale rural businesses will gradually disappear. Few will grow while most others have to be preserved by government support programs as they cannot create enough value in particular under conditions of continued economic growth. Supported small-scale rural businesses become a kind of insurance in periods of economic stress, shocks, recession, or under striking disasters. Rural workers and their dependents stay in rural places instead of filling urban slums and remain a flexible workforce needed for better times. They can still produce small value in rural areas when it is impossible to produce any value in urban areas. Small-scale rural businesses cover most of their food need in autarky of the trade system and keep rural landscapes populated. This can become a source for switching to higher value rural tourism.

\section{Resilience by insurance}

Insurance can be a tool to spread out local damage to a larger business community and to externalize damage. However, only a fraction of disaster damage is also insured (Munich Re 2017). The insurance rate of high-income countries can nevertheless reach up to $40 \%$ insurance rate. Medium income countries with the highest exposures such as Indonesia, Philippines, or Vietnam are as low as $6 \%, 4.09 \%$ or $0.21 \%$ despite a principally much higher insurance need while they are zero percent in less prosperous Cambodia, Laos, or Myanmar. Due to an even lower value at risk in these countries, there is no business model for insurers available to make them busy in a proactive way. 
Insurance is an additional service input to agricultural production and increases the cost of production. Only businesses already producing enough value can finance the extra cost. In low-income societies, trade-offs have to be made between investing into appropriate machinery or the education of kids. Disasters have a harmful impact on the income and human capital levels of poor households - and a decrease in either of them can result in a reduction of the other, thus creating a poverty trap. (Rentschler 2013).

The global index insurance facility (GIIF) is a World Bank Group's program facilitating access to finance for small-scale rural businesses and microfinance institutions through the provisions of catastrophic risk transfer solutions and index-based insurance in lower middle-income and low-income countries. The GIIF is funded by the European Union, the governments of Germany, Japan, and the Netherlands. GIIF has facilitated more than 4.6 million contracts, with USD 730 million in sums insured, covering approximately 23 million people, primarily in Sub-Saharan Africa, Asia, and Latin America, and the Caribbean. In combination, the international programs can only provide assistance to a minor share of small-scale businesses that would require such a support. If all smallholders would be insured this would mean USD 50 billion in sums insured which is $20 \%$ of average damage and losses registered in every year.

The southeast Asia disaster risk insurance facility program aims to improve governments' capacity to rapidly finance response to climate- and hazard-related disasters. This program aims to increase governments' fiscal capacity to manage the financial impact of natural disasters, and improve access to rapid response financing for emergency response (SEADRIF 2017).

\section{Business continuation and disaster recovery plans}

In 2012 an international standard for business continuation and management systems (BCMS) and business continuation and disaster recovery, BCDR was agreed by the International Standard Organization (ISO 2012) in Paris and is now relevant for all countries in the world. Its revision based on the reviews and experiences of international certification efforts was published in 2019 (ISO 2019). Business continuity planning involves preparation for any potential disaster by identifying all of the perceivable threats and analyzing their possible impacts on day-to-day operations.

Developing a range of scenarios such as being impacted by flood, drought, cyclones, and understanding what threats could affect the business and which of those could present a risk to business survival is critical. Those insights can lead to the uptake of an appropriate insurance, but critical risks are not likely to be insured. If once hit and compensated by an insurance after a disaster, the insurance is not going to insure for the same threat. Therefore, only $40 \%$ of damage and losses are insured on a global base. Businesses have always to consider those $60 \%$ for which no insurance agreement can be found.

What quantities can still be produced and supplied to consumers or business partners in a production chain? The ratio between emergency production and full production has to be named. Procedures on priorities in a situation of emergency have to be named. The plan has to indicate customers to be served first, second, and so on. If a key firm in a production chain gets affected then more or all partners will suffer from the disaster even though they are not directly hit by this particular disaster. Ways on how to relate with business partners in the production chains have to be documented. Actions for full business recovery have to be named and prioritized with regard to timely recovery. Finally, the BCDR plan has to be renewed on a regular basis, once within several years. 


\section{Changes in global rural value chains}

Rural value generation is subject to change. During the last decades even to accelerated economic change. Thereby long grown traditions on how to live and make business are challenged. The context of rural economy changed within two generations from primarily local to mainly regional and today predominantly global. This widely influenced business thinking all over the world. An attempt to divide rural value from urban value is undertaken here.

\section{Historic value is population growth}

Before the introduction of monetary value, rural success was measured as increase in population and food production for ever more people. Some 6000 years ago there is no distinction between the terms urban or rural. Everything is "rural" as we cannot find larger agglomerations in a world of an estimated 20 million people or 0.25 percent of today's global population (Whitmore et al. 1990). The place of production and consumption was identically or in vicinity and the analysis of value created would be straight forward. Based on the methods to convert wilderness to pasture or agricultural land, the human carrying capacity could alter mainly due to improved agricultural practice. But due to the absence or limitations of trade, the settlements remain small and primitive. In a local world, any kind of disaster could easily lead to catastrophes if food stocks cannot be filled or become too fast depleted. Hot periods limiting the availability of water or favoring growth of insects, wet periods stimulating fungi growth and pests, cold periods hindering plant maturation were all crucial for the (non-) availability of food and how many people could survive. People in malnutrition got easier sick and only progress of agricultural techniques enabled a comparatively slow growth of human population with repeated backlashes.

In 1700 the global population accounted between 600 million (Rosner 2019) or 679 million (Demeny 1990). This means a doubling of population every 1000 years. Along early industrialization, the world population grew to 2515 million people in 1950 or doubled twice during 250 years, the first time until 1850, the second time during a century until 1950 (Demeny 1990). Around 1900 and along two world wars, we can observe a paradigm shift particularly in high-income countries. The wealth of nations was no longer solely defined due to the growth of its population but also to the increase in values per person. A sophisticated economic system could develop first in high-income countries based on economic growth. While the old strive on population increase prevails in lower middleincome and low-income countries, wealthier nations gradually shift to value creation and away from population growth.

\section{Finite growth of rural population}

The wealth is directly related to population and people generating wealth as rural entrepreneurs and businessmen, employees and workers. The expanding radius of interaction allows a much wider scale of operation and consequently creation of higher value. Rural population is therefore the first indicator on the magnitude of wealth created in rural areas. In the following, we use data from international organizations. The World Bank to compiles data with indicators of global value and uses data from the Food and Agriculture 
Organization (FAO) to get agricultural value (World Bank 2019). The UN Department of Economic and Social Affairs (UNDESA 2019) and International Labor Organization (ILO) are providers for population data (ILO 2020).

Until 1950, the world counted less than one-third of today's 7631 million population (2018, UNDESA 2019) and the capacity to feed more people was almost entirely based on better ways to practice agriculture with still limited but increasingly more inputs from outside. Since 1960 the rural population increased in rural areas from 2 to 3.4 billion (Fig. 4). Over six decades high-income countries lost $19 \%$ of rural population, higher middleincome countries modestly increased their rural population with $6 \%$, lower middle income more than doubled their rural populations with $141 \%$ increase and low-income countries more than tripled their rural population with $243 \%$ increase.

While in 1950, most people lived within rural settings and more than $70 \%$ of the global population was rural, there are currently only $45 \%$ percent living in rural areas. There are important differences in high-income countries with only $20 \%$, higher middle-income countries with $34 \%$ rural population, lower middle-income countries with $60 \%$ and lowincome countries with $68 \%$ (Fig. 5). Currently, all groups of countries are under the average value of the world in 1950 and the further decline of rural is foreseeable everywhere. Since 1950 rural product and service chains get ever more economic impulses by urban growth dynamics.

Agriculture and in ever more countries tourism are lead economies of rural areas. They can be highly synergetic if products and services reach elevated levels. Based on the lead economies, we find industries and service sectors complementing rural value creation. Favorable rural locations can produce ever higher agricultural yields due to external resources availability in ever larger quantities. Global trade decreases the price of needed inputs to agricultural production and offers new possibilities to rural products and services all over the world. Digitizing agricultural businesses or converting them to smart agriculture businesses can be important means to get more rural value than otherwise possible (Wolfert et al. 2017). The development of recreational areas for urban citizens in nearby rural areas or the coming up of rural tourism is important new businesses and means for value creation.

\section{Economic growth and shrinking share of rural value}

Current data collection of international organizations such as the United Nations Division of Economic and Social Affairs (UNDESA 2019) or the Word Bank Global Indicators (World Bank 2019) allows an approximation by using appropriate indicators to assess the total global value rural value. Figure 4 depicts global GDP or economic value and its growth during 1960 and 2018 and the shares by four economic groups of countries based on their income characteristics. We employ in this article the classification provided by the World Bank (2019). High-income countries generate a per capita income over USD 12,375 with 80 countries including the US, Japan, South Korea, many European countries, all OECD countries or Brunei Darussalam and Singapore from ASEAN countries. The border between high income and upper middle income is very close to the average income of a global citizen in 2018 with USD 11,244. Upper middle-income countries comprising 60 countries enjoy per capita incomes ranging from USD 3996 to 12,375. In this group, we find China or Russia and ASEAN countries Malaysia and Thailand. The 47 lower middle-income countries earn USD 1026 to 3995 and include India, Nigeria or most of the ASEAN countries, namely Cambodia, Indonesia, Lao, Myanmar, Philippines, Viet Nam. 


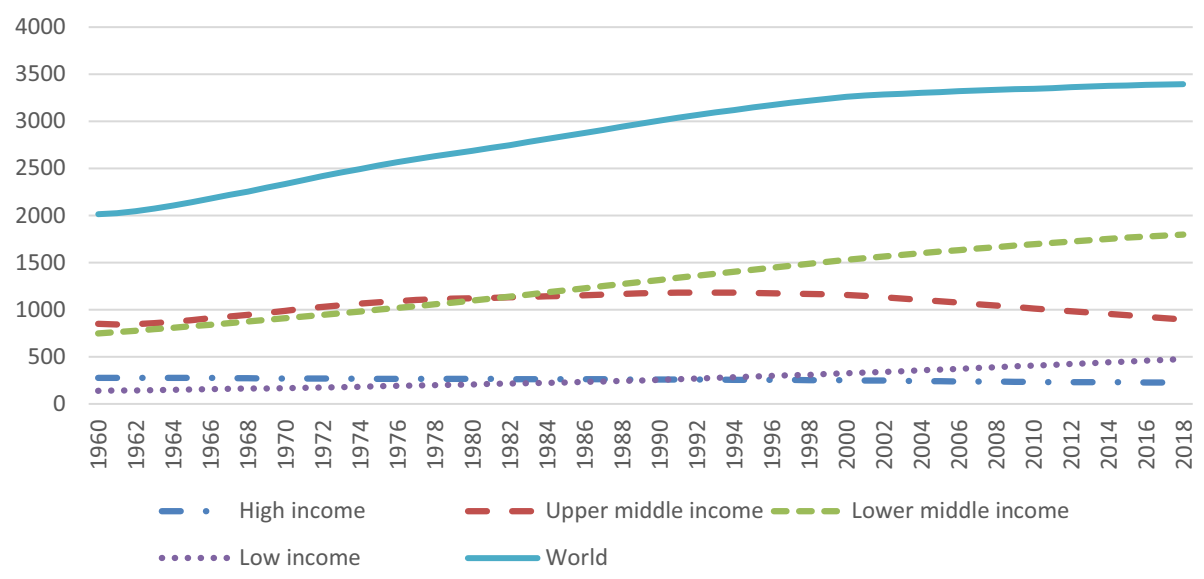

Source: World Bank 2019, UNDESA 2019,

Fig. 4 Rural population 1960 to 2018 in million Persons

Low- income countries earn USD 1,025 or less per person. Here, we find 31 countries, many of them in situations of civil war or crisis like Syria or South Sudan, hindering an appropriate creation of wealth and value.

The global value or the final output of all—rural and urban value chains alike — is global GDP. Initially, in 1960, the sum of all value chains in the world was low or just 1.3 trillion current USD. The value of 2018 multiplied to 86 trillion current USD or 63 times the original value (World Bank 2019). In average, we had at every decade a doubling of global GDP.

One-sixth of the global population living in high-income countries creates $63 \%$ of global value. The income of five sixth of global population living in countries of the three other income categories generates jointly $37 \%$ of global value (2018). The absolute value in high-income countries was 54.1 trillion USD value in 2018, coming down from the highest share of $85 \%$ in 1992 and second-highest share of $83 \%$ in 1999. Upper middleincome countries contribute with an ever larger share of $29 \%$ or 24.4 trillion USD in 2018. Lower middle-income countries increased their share to $8 \%$ or 6.7 trillion USD in 2018 and low-income countries stay with less than $1 \%$ of global value or 610 billion USD in 2018 but become more noteworthy in global value creation.

\section{Lower border to rural value estimate: agriculture value as proxy}

An important indicator for rural value is value added due to agricultural production (Fig. 5). There are some remarks to use agricultural value as a lower border estimate for rural value. First, even urban areas can have substantial agriculture. Second, even if agriculture is the lead economy of rural areas, there is industry and services and rural value should be much higher than indicated by the agricultural value. The industry and service activities gradually took shares from agriculture. In 1960, the start is 120 billion USD global value or 9 percent of GDP and in 2018 the created value ends with 3.34 trillion current USD or 3.9 percent of global GDP. This means a doubling of the agricultural GDP every 12 years or a considerable slower growth than the rest of business activities. Over the 


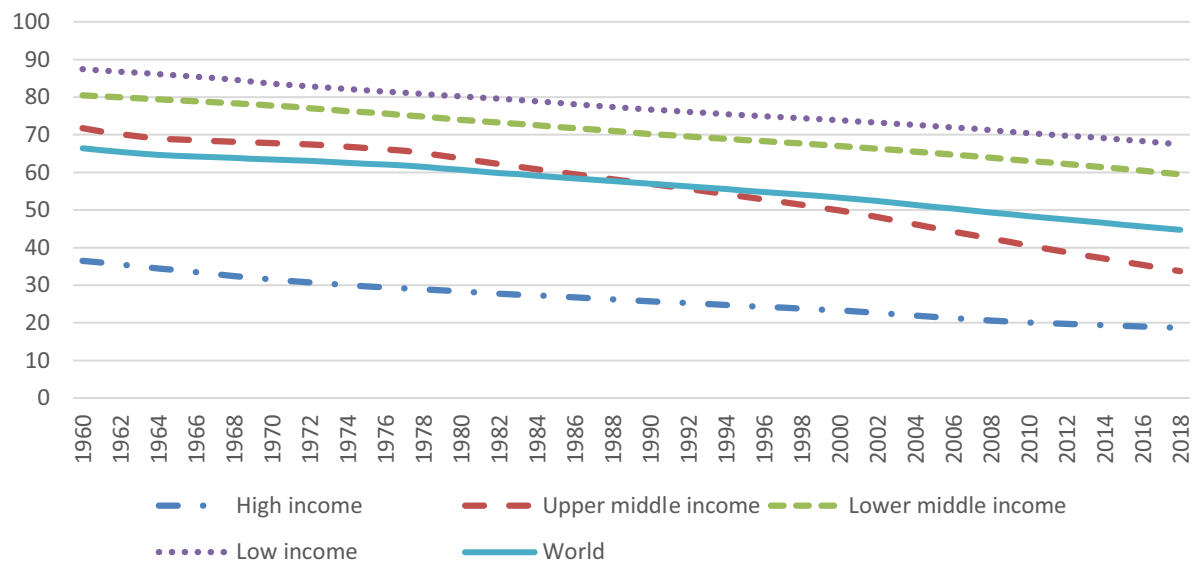

Source: World Bank 2019, UNDESA 2019,

Fig. 5 Rural population 1960 to 2018 as percent of total population

observed period, the performance of agriculture was just half of the combined performance of all other economic sectors (Fig. 6).

When we split the global picture into four income groups of countries, the situation is dissimilar. The decline of agricultural value in high-income countries was from 6.9 percent in 1960 to 1.3 percent in 2018. The decay was greater in upper middle-income countries starting with 23.1 percent in 1960 reaching a peak with 27.3 in 1963 down to 6.3 percent in 2018 (Fig. 7). The decrease in value of agriculture in lower middle-income countries was waning from 33.4 percent in 1985 to 14.9 percent in 2018. Low-income countries remain

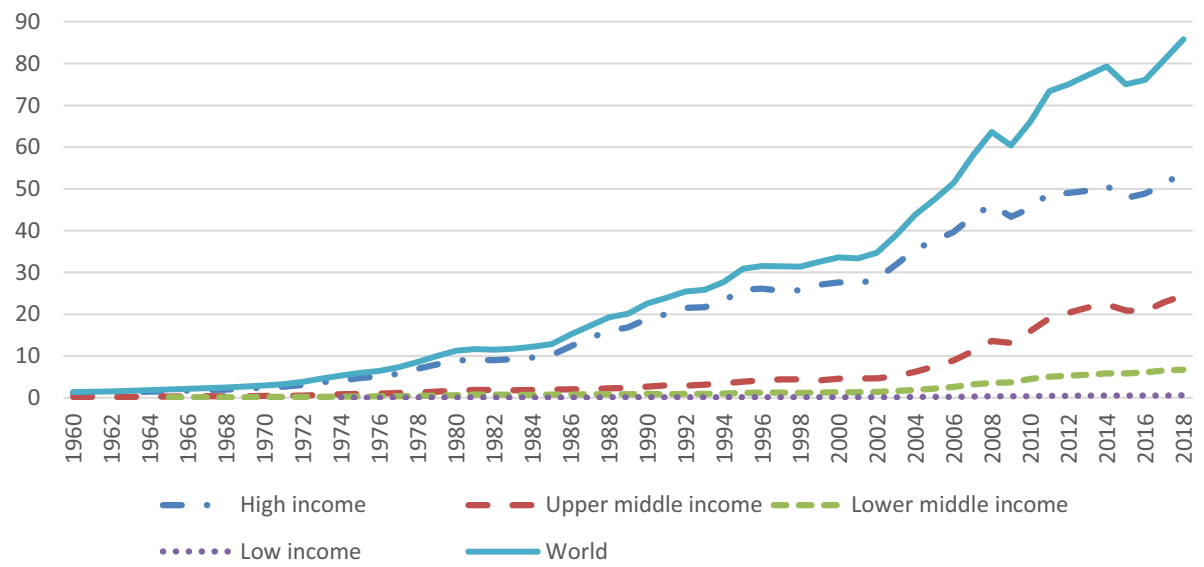

Source: World Bank, Global Indicators, Update September 2019

Fig. 6 Global GDP and economic growth according to groups of countries 1960 to 2018 in trillion current USD 


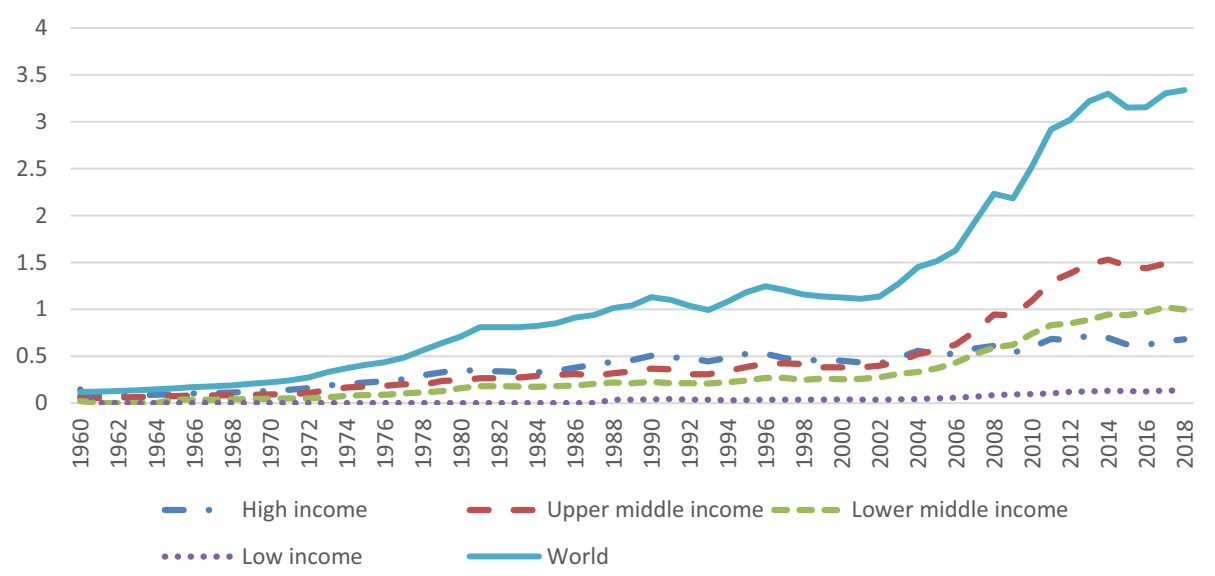

Source: World Bank 2019

Fig. 7 Value of agriculture in trillion current USD. Source: World Bank 2019, Global Indicators, Update September 2019

widely dependent on agriculture starting with over 50 percent in 1960, coming down to 38.4 percent until 1985 and are currently at 22.7 percent (Fig. 8). Agriculture in lower middle-income and low-income countries has also to be seen in the context of subsistence agriculture and to supply poor people with food and lacking capital to escape to a better off situation. In many cases, little or no extra value can be created and local societies remain in particular vulnerable to all kinds of natural disasters.

The income groups of countries provide average values for each income group of countries. Agriculture is up to our days a main source of income for countries of the world.

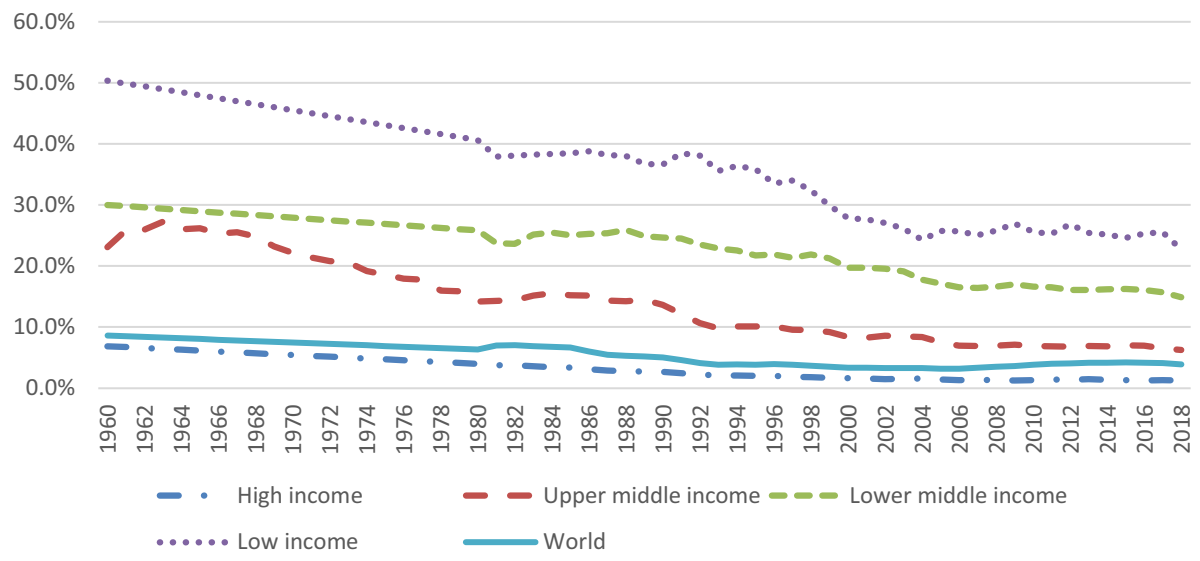

Source: World Bank 2019, Author interpolation of some missing values in period 1960 to 1985

Fig. 8 Agriculture as a share of GDP Source: World Bank 2019, Author interpolation of some missing values in period 1960 to 1985 
Sierra Leone is the country with the highest share of agriculture in 2018 accounting for 60 percent of annual value due to agriculture and Singapore as an urban state has the lowest number with only 0.03 percent of the national income due to agriculture (World Bank 2019). On the global scale the value of agriculture went down from 8.6 percent in 1960 to 3.9 percent in 2018.

The agricultural per capita value of high-income countries was increasing from USD 39 in 1960 and ending with USD 437 in 2018 after a peak in 2014 with USD 452. The lead in creating agricultural value is now with higher middle-income countries. In 2014, each inhabitant of these countries generated in average USD 600 in value and in 2018 this value was USD 584 or 40 above high-income countries. Lower middle-income countries reached a maximum of USD 344 in 2017 or two thirds of high-income countries, while low- income countries generated a third of the agricultural income of high-income countries. It is remarkable that the agricultural value is more equally distributed over countries than GDP. High-income countries earn three times more value in agriculture per capita than low-income countries, while they create 71 times the value of total income.

\section{Upper border rural value estimate: average per capita income times rural population}

Agricultural value does not consider other rural value. Rural has also shares in industrial businesses or commercial services. In particular food and tourism industries are part of the rural GDP. Buildings, constructions, food processing, wood manufacturing, and energy generation are industry-related businesses in rural value chains. Rural tourism and recreation services directly relate to increasing urban populations. Urban value is in general much higher than rural value and above the average per capita income.

The per capita income (Fig. 9) multiplied by the rural population (Fig. 4) is the upper border to rural value in Fig. 10.

The per capita mean income does not consider differences within classes of rural. For many rural areas, the upper limit to rural value as mean income is too high but it is mostly

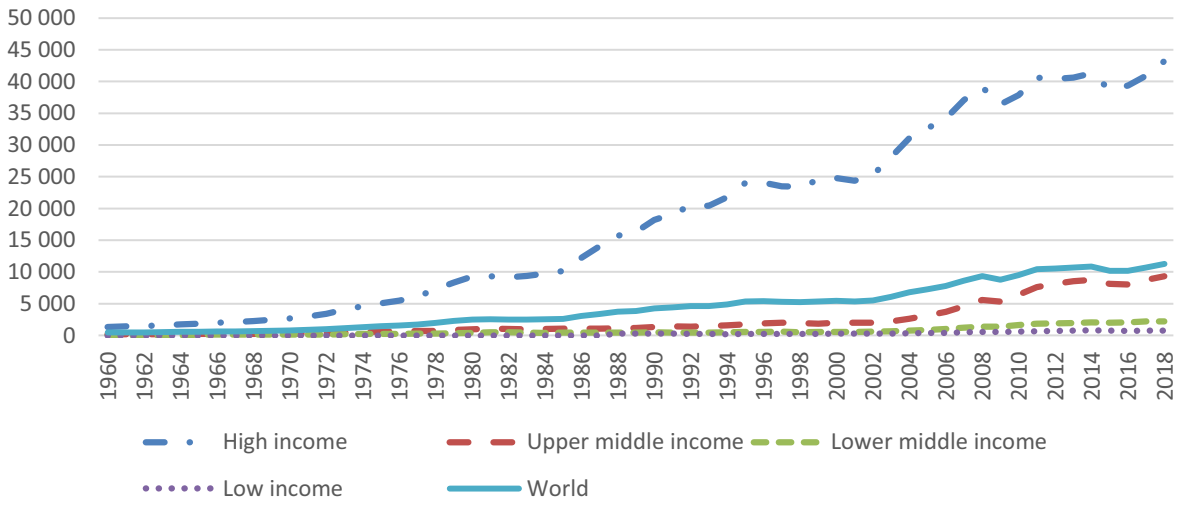

Source: World Bank 2019, UNDESA 2019, author calculation

Fig. 9 Per capita GDP in current USD 1960 to 2018 


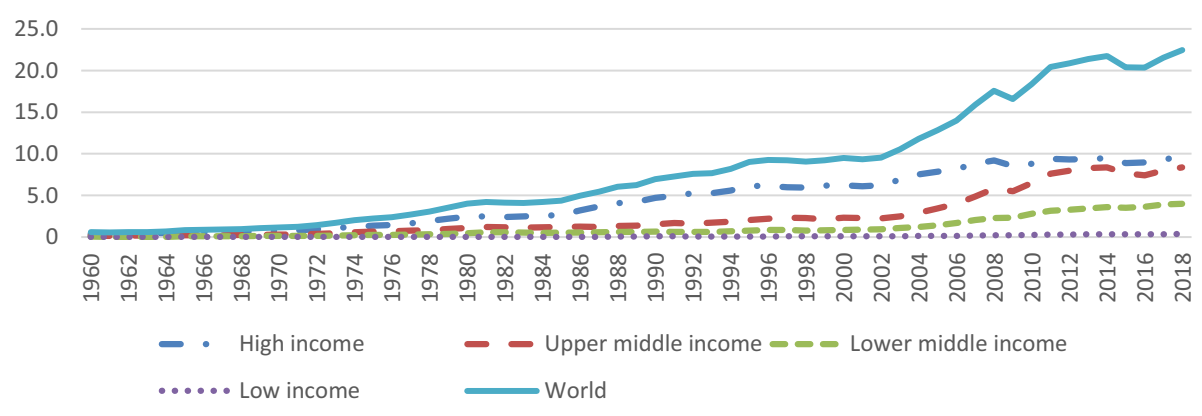

Source: World Bank 2019, UNDESA 2019, author calculation

Fig. 10 Rural value based on population and average per capita in trillion current USD 1960-2018

reached in near center rural locations. In 2018, this upper border to rural value was 23 trillion USD or $26 \%$ of global GDP.

\section{The best guess of rural value in dependence of distance to economic center}

The urban to rural transition zones or the intermediate belts around urban areas are different to rural areas in the periphery. The share of industry and services will be considerable higher than in remote areas and accordingly the value earned per person. Differences of rural within the same country can be substantial. In Austria, the difference in the average value creation per inhabitant of two rural districts within the province lower Austriasome $30 \mathrm{~km}$ and over $100 \mathrm{~km}$ away from Vienna-exceeded 2.3 times due to a different mix of business shares of agriculture, industry, and services which is related to the better access to the center (Geldner and Jeglitsch 1976).

The agricultural value in national income as a lower border and average per capita income multiplied by rural population as an upper border to rural value provides the borders to actual rural value. Particularly in low-income countries with high shares in agricultural values or remote locations, the borders of rural value are close to each other. The more income a country enjoys the higher the difference between the lower and upper border will be. In near center locations, the rural value will be close to the upper border (Fig. 10), while in remote areas, the rural value will be close to the lower border (Fig. 7). If we take the center of the lower and upper border of rural GDP, we get a rural value of $15 \%$ share in global GDP for 2018 (plus or minus 11\%).

Some low-income countries are out of considerations to estimate rural value. They have difficulties in creating value on their rural lands as they are often in struggle for survival. Civil wars and conflict widely disturb development. Trade is impossible or prices of goods are far too high for most people. Natural disasters have a much stronger impact on the economically weak low-income countries. Shocks provided by climate and extreme weather events can have devasting consequences and further heat up conflicts. Often the international community has to support these countries with emergency aid, primarily food imports. High rates of people occupied in agriculture and dependence on agricultural income describe a situation of a disturbed business environment with prevailing conflicts hindering an appropriate value creation or decent work for rural population (ILO 2019). 


\section{Case studies of upgrading rural value chains and the impact of disasters}

There are different ways to alter rural value chains in unalike directions. One group of options is to shift priorities within agricultural production and to proceed from local agricultural value chains to regional or even global ones and use comparative advantages in producing agricultural commodities. The focus is continuously on agriculture and how to increase agricultural productivity. A second group of options is to advance from low value agriculture to higher value industry and service production, such as establishing food industries or tourism services in rural landscapes. We exemplify the upgrading of rural value chains on four examples.

\section{Palm oil value chain in ASEAN}

Indonesia and Malaysia started with palm oil extension during the 1990ies, most of the conversion happened in this millennium and the renewal period of palm oil plantation lasts some 25 years. The clearing event gives a first dividend to developers by selling timber, the palm oil plantation is then the second dividend, but due to the relative new extension of palm oil plantations long-term affects can lead to major costs and widely reduce profits at a later stage of the palm oil plantation life cycle. As long as virgin tropical forest is inexpensively available, pressure to convert land to palm oil production will remain very high.

In particular, Indonesia with an area of over 12 million ha and Malaysia with more than 5 million ha and to a lesser extent Thailand with about one million hectares expanded their territory of oil palm production yielding currently some 66 million tons (USDA 2020) of crude palm oil or close to $90 \%$ of the world production. Crude palm oil has steadily risen market shares within the group of vegetable oils. This is reasoned in an extraordinary efficiency of palm oil that outperforms other oil fruits. On just 5.5 percent of global oil fruit area, some $32 \%$ of global oils and fats output is yielded (Falatehan and Setiawan 2020). This roughly equals to $10 \mathrm{~kg}$ per person on earth and year with $9 \mathrm{~kg}$ coming from ASEAN and thereof $6 \mathrm{~kg}$ from Indonesia.

One source of new palm oil area was the conversion of forest and peatland to palm oil plantation. Alternatively, palm oil plantations were established on existing crop land. An expected consequence from the conversion is soil fertility decline and water scarcity besides a loss in biodiversity. During 1990 and 2015 the Indonesian area of palm oil increased by annually $9.9 \%$, while the growth rate of crude palm oil production was 6.6 percent (Faroby and Setiawan 2020), This indicates that with continued extension less productive soils are used for palm oil plantation.

Palm oil plantations are considered a huge environmental threat, and in particular, the clearing of forest with fires is considered unsustainable. In 2015, a 4-month long-lasting fire and haze disaster stretching overvast peatland and forest areas in Sumatra centered at Jambi Riau in Sumatera Selatan and in further four Indonesian provinces in Kalimantan caused a damage of 1 billion USD (Guha-Sapir 2020). The fires followed the drainage and dry out of peatland intended to use for palm oil plantations. In Jambi province of Sumatra, Indonesia, the conversions of rain forest ecosystems to oil palm plantations led to a redistribution of precipitated water by runoff and periodic water scarcity and a loss of top soil layers (Merten et al. 2016). For the time being further extension of palm oil plantations is 
prohibited. While the government obliged itself for 3 years to abstain from extension such as in Papua, citizen groups and locals opt for a permanent prohibition (Mongabay 2018).

In case of the wildfires event of 2015, the disaster was triggered by current land use practices. Disasters in Southeast Asia have a principal higher impact on new palm oil plantations than on forests and peat soil land that are very stable ecosystems existing for millions of years. Disasters meet now less environmental resilience and the long-term effects of the land use change are still open. While the event of 2015 impacted vast land areas with relative scarce populations many smaller-scale events is not considered in the CRED database. While currently, extensions of palm oil are illegal, they happen nevertheless on the unattended smaller scale.

There are counter moves on the way arguing that any other vegetable oils would cause much more need in land and spin off projects to save orangutans could not be financed without such an attempt. The certification of palm oil as sustainable palm oil is demanded since 2004. The EU is with $16 \%$ of all global production the second-largest importer after India (22\%) and before China (13\%) and Pakistan (7\%) (Faletahan and Setiawan 2020). In 2019 and after years of discussion, there are currently $86 \%$ of palm oil sustainably certified within EU, while the aim was to achieve a $100 \%$ supply by this year (Palmoilalliance 2020). Certification as sustainable palm oil is a means to increase the value of palm oil and to sell it to selected countries for a considerable higher price. Additional steps and independent control services are required to obtain such a certificate.

Palm oil plantations altered the value produced in ASEAN agriculture substantially. This was often at the expense of tropical forest and biodiversity loss providing hitherto not or not adequately evaluated services for people. With higher incomes and state revenues former free services can gradually become also paid services that further increase the value creation and guarantee a proper maintenance of land resources. Many countries that do not convert their forests to higher value agricultural lands receive compensation payments by the REDD+, an initiative from UN to secure forest stands (FAO 2020). Indirectly, the economic success of the palm oil value chain contributed to the higher monetary evaluation of tropical forests too. This provides room for a later introduction of compensation schemes for other managed eco-system services.

\section{"6th economy" and Japanese food value chain extension}

Rural value adaptation strategies can be highly diverse in industrialized countries. During 2009 to 2017 business performance of one worker in US agriculture was $81 \%$ of the national per capita income (Duffin 2020), while it was in average $30 \%$ of the national per capita income in Japan (Plecher 2020a, b). While a small number of 1.4 percent of US workforce was employed in agriculture and could adjust to a much higher agricultural output and value, in Japan the workforce in agriculture kept at 3.8 percent with a high percentage of female and aged workforce and the value creation was very low. At a certain point, business profitability will stop and not only businesses but also rural places can disappear if no innovative business strategy can be found and implemented. Alternatively, the launch of state programs like in Japan was responsible that rural settlements remain populated.

While US kept profitability of agricultural businesses due to the economy of scale at the expense of people occupied in agriculture and giving up marginal income farms, Japan chose the opposite strategy and to protect a grown settlement structure by supporting its farmers and preserving the agricultural landscape also as an asset for rural tourism (Breiling 2005). While US went into intensification, Japan chose diversification of its rural business model. In both 
cases, substantial support to rural businesses is provided by the states in form of export subsidies or in form of rural development programs.

The so-called "6th economy" build on the principle that primary production is not sufficient for rural value generation. Instead, decent rural value will only follow by employing the other sectors, the secondary sector and the tertiary sector. Based on the first, the second, and the third together, the term "6th economy" was born (Kodaira 2016). The "6th economy" was exemplified by the food value chain of Japan (Yamaji 2020). Taking the fiscal year 2013 the earning of the first sector was 9.4 trillion yen. Only $40 \%$ of calories are produced in Japan. The remainder has to be imported. A value of 1.2 trillion is additionally imported as fresh food. From the fresh food, now representing a value of 10.6 trillion, 3.3 trillion are directly taken to the market. These fresh food items are sold for 13.5 trillion or roughly 4 times the original value under which they were produced. Fresh food items in value of 6.6 trillion yen and additional preprocessed imported food items in value of 1.4 trillion yen are processed by Japanese food industry and lifted in value to 30.1 trillion yen again almost four times the original value ending up in the wholesale market. The consumers finally buy the processed food for 39.1 trillion adding another 30 percent to the value of food. The final 0.7 trillion yen of fresh food and a part of processed food is used for eating out in all kind of categories. Again, the value is multiplied by some five times due to eating out. Eating out belongs to services and the third sector and involves all kind of sectors, first farmers, second industry, and third service. Selling fresh food involves first and third sector. Processing food involves first and second sector. So, having the advantage of the first link in the business chain, Japanese farmers should start to create more value by selling their products or in the best case even prepare meals to sell as this provides the highest value.

In Japan, some 60,000 companies overtook the concept of "6th industry" and all over the country farmers formed associations to promote the concept in community- owned sales halls, often along public highways leading through their area and thereby promoting food and other products. Variants of this concept swept over to other programs like gastronomy tourism (UNWTO 2019 and 2019a). There, in towns nearby, entrepreneurs directly coming from farms or having good links to the primary sector started with local cuisine and could sell considerable higher than what is possible in sales halls. The well organized and typically local food value chain can thereby alter the value to a performance which is impossible to gain if single food or food items markets are considered. Usually, these concepts go well hand in hand with smaller scale or rural tourism promotion.

In the case of triple disaster in Fukushima on March 11, 2011, earthquake, tsunami followed by nuclear fallout the connected sector was seriously disrupted. Japanese food was considered as dangerous despite only in an exceptional case there was a real danger. It took month until the trust of consumers could be reestablished. The Fukushima triple disaster would have ruined many rural value chains if no government interventions would have happened. For a long time, a bad business reputation limited the sales in all three sectors, and Japanese food export products still suffer almost 10 years after the disaster. Some 20 countries still restrict Japanese food imports, under them the five most important export nations Hong Kong, China,the USA, Taiwan, and South Korea (Morita 2020).

\section{Emerging rural tourism value chains in Asian middle-income countries}

Rural tourism is emerging in many countries of the world and a main reason to create more value in rural areas. Recently, many high, upper, and lower middle-income countries started initiatives to promote rural tourism (UNWTO 2017; OECD 2020). The service 
infrastructure of tourism employs higher value buildings and constructions and a successful tourism establishment means a value upgrade. In addition to the mentioned, we find public services like schools, hospitals, and transport infrastructure that also contributes to rural value.

China is an example for an upper middle-income country. During 2009 and 2017 the value of agriculture went down from 10.3 percent to 7.5 of the national value or 9 percent in average of the whole period (Textor 2020). The number of people occupied in agriculture went down from 40 to 26 percent or 32 percent in average of the period. The average value added by employed person was 28 percent of the national average. This explains why there is a fast and substantial migration from rural to urban. In particular, the difference to industrial value per capita is huge and each worker in industry earns in average five times more than a worker in agriculture. Poverty due to low value earned in agriculture is therefore a serious issue. During 2016 and 2020 based on its 13th 5-year plan, the Chinese Government targets to lift $17 \%$ of the rural population out of poverty with rural tourism (Koleski 2017). One trillion CNY or 150 billion USD annually can help three million rural tourism businesses with 50 million dependent people to make a decent living at the countryside. The average value targeted by each business is USD 50,000 or USD 3000 per dependent person (UNWTO 2017). With regard to the total population with 1.37 billion, some USD 110 yearly value are created per person until 2020 or USD 325 per one employed in agriculture. At least one in ten should change occupation from agriculture to tourism within the rural location instead of moving to urban areas. This rate might also be used as a proxy for all higher middle-income groups.

India as the most populous country of the lower middle-income group is economically not yet at the same stage like China. Here, some $40 \%$ of the global poor people live and they are mainly occupied in agriculture and create very small value. During 2009 and 2017 almost half of Indian workforce, 47 percent, were occupied in agriculture. Each worker occupied in agriculture earned roughly one-third, 35 percent, of the average workforce in India (Plecher 2020a). Agriculture is in many locations more an activity to avoid hunger and costs than a business to create extra value. The agricultural workforce in India is a powerful reserve and can release hundreds of millions workers to create more value in other business sectors. This in turn will gradually increase support for agriculture and rural development programs. Similar to China, many Indian states like Kerala (UNWTO 2017) promote rural tourism as a mean to gain higher rural value. With increasing rates of urban populations, the demand for recreation and holidays in rural areas becomes more requested.

Besides, ASEAN countries like Indonesia, Malaysia, Myanmar, Thailand, Vietnam developed programs to enable farmers and local villages to increase their income level by developing targeted attractions or experience products by local people and not by special agencies or developers from outside (UNWTO 2017). With support of special consultants and targeted provincial or state programs, locals develop experience products by organizing fishing tours on the sea, to climb volcanoes, to teach tourists the production methods of particular crops like coffee, tea, spices, and story telling about the destination of concern. The targeted market is either urban people longing for a break or international tourists. Tourists stay with locals in simple, traditional houses and eat traditional foods from local people. Sometimes the number of tourists or the duration of stay is not considered as long enough to make a viable impact. Many of the programs are still in an emerging state and locals are improvising and innovating to find appropriate forms.

The relative low value at risk indicates poor rural areas as much more vulnerable to natural disasters. The possibilities to adapt to a changed climate or climate variability are much more difficult if the area under consideration is large and the value to protect 
is relatively low and appropriate financial means are lacking. Rural businesses in disaster impact areas can substitute lost agricultural harvests by importing food from other regions. Thereby disasters can break established regional business links.

Small-scale rural food production in remote areas is no longer needed from urban view point unless the business upgrades to a particular precious food brand or eventually shifts to organic food production which can increase values by many times. In combination with rural tourism restoring traditional villages and offering tourism experience services will boost rural value chains. Being closely linked to urban value chains they can create much higher value for traditional agricultural, regionally branded products, or rural tourism experiences and become thereby disaster resilient.

Heat waves, cyclones, flooding or landslides, earthquakes, and tsunamis are forms of disasters tourists have to be aware about in most countries. In many cases in particular, when starting the activities of rural tourism locals do not speak English which makes it difficult to communicate disasters appropriately. Some recent observations are that patterns of dry and wet season following long times a typical pattern became more varied. The promised tourism experience might not be ready at the time when tourists are present in particular if they follow tight schedules.

\section{Austrian rural value chain upgrade due to winter tourism}

Austria in Europe shows a remarkable rural value chain which is unmatched in high-income countries. Beside agriculture and forestry providing some 1.5 percent to national GDP, we find sophisticated forms of tourism. Both Austrian summer and winter tourism are principally rural and are responsible for 2.5 and 3 percent to GDP. In 2019, there were 46 million tourist arrivals consuming over 150 million guest nights or 3.3 nights per arrival. Summer tourism-covering tourism during May and October-counted for 80 million guest nights and winter tourism-including all month from November to April-yielded more than 70 million guest nights (Austriatourism 2020). Summer tourism is more widespread and covers also non-Alpine regions, while winter tourism is primarily consumed in mountain destination. Prices in winter are higher than in summer. Winter tourism is snow based and also more dependent on technology (Breiling 2020).

Just after WWII, summer tourism started to develop and grew from 18 million in 1951 to 80 million guest nights in 1970, quadrupled in only 20 years and is since then fluctuating at this high level. In 1951, winter tourism started from 4 million and grew steadily to actually 73 million guest nights. While in many high-income countries, the share of rural value was continuously shrinking, it kept stable in Austria. Austria and Japan roughly have a similar per capita GDP, but differ widely with the value earned in rural settings. Austria is thereby profiting from a central position and can be easily accessed from Germany, the main market for tourists. In Japan, the tourism started to develop at a much later stage, mainly after the turn of millenium. While in Japan, we find huge income differences between urban and rural citizens in Austria we have only minor differences.

The first layer of rural economy is agriculture, the second one is summer tourism and the third one is winter tourism. With each layer, the rural economy gets more sophisticated and valuable. Winter tourism is snow based and initially snow was not evaluated for in terms of money. In the early days of winter tourism snow was natural and the practice of winter sports depended entirely on natural conditions, cold temperatures and precipitation falling as snow in dependence of altitude and relief. Along with skiing competitions and tourism increase, snow manipulations were required to optimize snow conditions for 
winter tourism. Starting in the late 1970ies snow guns were introduced in some ski areas to start the season earlier. From here, an extension of technical produced snow was and still is going on as a means of adaptation. This coincided also with climate change and warming in the Alps. Natural conditions to practice skiing worsened in particular in the lower situated ski resorts. Snow making, in many aspects resembling irrigation in agriculture, takes most water resources of all land uses in Austria. While maize, onion, and potatoes depend on up to 2001 per $\mathrm{m}^{2}$, the amount is several times higher in the case of snow making. In Austria $70 \%$ of all ski slopes are equipped with artificial snow making infrastructure. For 17,000 hectares irrigated ski slopes area, some $0.2 \mathrm{~km}^{3}$ water $\left(200\right.$ million $\left.\mathrm{m}^{3}\right)$ per season is necessary to supply the area with an appropriate snow cover of some $30 \mathrm{~cm}$. A problem is the duration of snow cover in an ever-warmer environment and the window of opportunity to make snow with machines. Snow is melting away during more frequent heat peaks and often one has to start several times to produce the initial snow cover of $30 \mathrm{~cm}$ snow depth. The inexistence of an appropriate snow cover is, however, the worst threat to the winter tourism industry as this will hinder skiing. In Austria, a water-rich country, it is possible to build out ever more reservoirs to collect water to compensate for increasing demand.

Austria has today the largest agglomeration of winter tourism resorts. Some 300 major ski resorts within an area of $50.000 \mathrm{~km}^{2}$. While other countries and regions less dependent on winter tourism, e.g., Japan with some 800 primarily smaller-scale resorts, widely gave up to adapt ski slopes for winter tourism (Fukushima 2002), Austria is adapting in ever more sophisticated ways. Snow making infrastructure, lift capacities, and speed of transportation to the mountains increased and the guests obtain every possible service offer to make skiing more attractive. This results in annual investments of 0.5 billion Euro into winter tourism infrastructure. Often local governments provide additional support to secure the flow of winter tourists. Due to this support winter tourism businesses are viable, but it is not guaranteed that ever more sophisticated levels of adaptation are physically possible and financially feasible. It became more exclusive and attracts 70 percent foreigners making it an important export commodity. So far, climate change and warming have stimulated the development of tourism by allowing innovations to enter. Adaptation was a means to activate further growth in the winter tourism value chain. However, gradually lower elevation ski resorts are going out of business while higher elevation ski resorts can still gain more value.

\section{Conclusion}

Disasters generate mixed significances according to the people-environment-value context. While in one case, a disaster is ruining the base of life the same disaster can trigger innovation and further growth in the other cases. Global rural value chains allow businesses to reach partners all over the world and to import and export goods and services. In consequence, while reaching out ever further in the global scale, successful rural value chains are likely to contract in the local scale and can leave marginalized land behind.

The impact of disasters to rural areas was much more dangerous in historical times due to scarce populations and limited possibilities for interactions to counter them. Many more people died in relation to the overall population. But the values lost at single disaster events 
were much smaller as most assets were not evaluated for. Along with a higher value creation, the damages and losses increase.

The highest impact to disaster resilience is the impact of trade and its continuous growth. Failed harvests meant famine or even death only a century ago, but can be traded today inexpensively from far away and most likely from several places. Ever more people in rural areas take part in trade activities. The backside of this is redundancy of many products and services.

While parts of the world, region, or country lose profits and development potential other parts can revenue from disasters due to better prices for their products or services under decreased competition. More disasters mean more fluctuations, price insecurity, and difficulties in business operations but not less global value. Disasters can be game changers as they take value from one side and pass it over to the other sides. Higher values earned allow businesses to consider new services like a weather insurance for agriculture. Businesses can continue after failures, while noninsured firms may step out of commercial operations.

Disasters accelerate the global divide between small-scale rural and large-scale rural or urban businesses. They will clear many rural zones from already marginal business activities. Traditional rural systems are going either to change to higher value or to parish. The subsistence small-scale rural agricultural system is suited to make a living in a closed unit with endogenous values and rules. When trade and exchange are barely possible, it ensures survival. Today the world is more homogenous and people strive to higher economic values. People, in particular the younger generations, incline to leave low value areas and disasters will accelerate their migration to better off areas. With higher values earned more people will also become disaster resilient as they have gained access to products and services from the global market.

Accounting methods for damage and losses caused by natural disasters in rural businesses are imperfect, vary from country to country, but will become more sophisticated and homogenized over time. While absolute values at risk will further increase in many rural areas, relative numbers of values at risk will decline as urban areas increase their share in global value creation.

Disasters do not necessarily have to be adverse. In some cases, disasters can even trigger business development. If insured, extra money will flow into the area and can be used to modernize business operations. Natural disasters can so become the source of new development. However, it depends where a disaster occurs. If it is in a central, strategic location, the restructuring has to go very fast to avoid further business failure. The room for business innovation will be limited. If a disaster hits a wealthy area, where many businesses are insured, it can have a benign medium- or long-term effect on business development. After the immediate shock, there is room for business innovation and after a certain period the business is in a better state than what it would be without a disaster.

Value chains without a viable rural hinterland are highly vulnerable to threats imposed by climate change, natural or human disasters, epidemics, and other shocks. Climate change and an anticipated increase in climate-related disasters like floods, droughts, cyclones, or climate extreme events will decrease business profitability and profit margins in value chains and increase in particular the vulnerability of climate-dependent rural value chains.

Rural value chains are important in the management of local and regional resource reservoirs. Higher rural values can make entire regions more resilient. They decelerate rural to urban migration and provide basic food security for the central population otherwise solely dependent on food imports. We discussed four value chains describing successful 
alterations of rural value chains. Value increase is, however, not a usual case. During the last decades, many rural value chains experienced decreased profitability and shrinking.

The urban-rural transfer already working in agricultural programs of high-income states needs to be built out in higher middle and lower middle-income countries or to be established in low-income countries if dependence on emergency relief programs of the international community should be reduced. The inhabitants of low-income countries suffer most from disasters and rural value creation is especially difficult here. Many rural areas are today out of scope from a value perspective and will not become part of a value chain unless state programs are in place and support higher value initiatives like rural tourism or ecotourism. In times of economic crisis, their rural homelands are important hinterlands to buffer periods of economic crisis.

What is rarely considered in business plans are future costs due to the decline of environmental quality or the depletion of nonrenewable resources like soil or groundwater. The re-establishment of a good resource status can become a new business in future. Considerable parts of the agricultural land are today degraded and need restoration for regaining lost ecological performance. Water purification, retaining water in the landscape, cooling regions, avoiding soil erosion or biodiversity increase financed by an urban public can become eco-system services provided in rural landscapes. Ecological restoration and the value going out of functional ecosystems or marginal rural lands will be more appreciated with further decline of their ecological status. At a certain point, the reverse will be reached and degraded land becomes a business model for new rural entrepreneurs under the expectation that the urban society is paying for their services. The effect of disasters will not be triggered like this is today often the case. A proper management of land resources will also keep the impact of disasters at a minimum level. Functioning landscapes with vegetations holding back fertile top soil layers with a maximum water retention capacity can balance adverse climate effects.

Funding Open Access funding provided by TU Wien (TUW).

Open Access This article is licensed under a Creative Commons Attribution 4.0 International License, which permits use, sharing, adaptation, distribution and reproduction in any medium or format, as long as you give appropriate credit to the original author(s) and the source, provide a link to the Creative Commons licence, and indicate if changes were made. The images or other third party material in this article are included in the article's Creative Commons licence, unless indicated otherwise in a credit line to the material. If material is not included in the article's Creative Commons licence and your intended use is not permitted by statutory regulation or exceeds the permitted use, you will need to obtain permission directly from the copyright holder. To view a copy of this licence, visit http://creativecommons.org/licenses/by/4.0/.

\section{References}

Austriatourism (2020) Kalenderjahr 2019: mit 153 Mio. Nächtigungen und 46 Mio. Ankünften über Vorjahreswerten. https://www.austriatourism.com/fileadmin/user_upload/Media_Library/Downloads/Touri smusforschung/2020G_Kalenderjahr_2019__Hochrechnung_ZusFassung.pdf

Banholzer S, Kossin J, Donner S (2014) The impact of climate change on natural disasters. In: Zommers Z, Singh A (eds) Reducing disaster: early warning systems for climate change. Springer, Dordrecht

Blaikie P, Brookfield H (1987) Land degradation and society. Routledge, Abingdon

Breiling M (2005) Rural tourism: experience from austria and opportunities for Japan. In: Landscape planning and horticluture. Journal of awaji shima landscape planning and horticultural academy ALPHA, vol. 7/1. pp. 1-11. http://breiling.org/publ/ruraltour.pdf. Accessed 1 Apr 2020 
Breiling M (2020) A contingent resource-based perspective of tourism value chain and robustness: European experiences. Springer, Dordrecht

Breiling M, Anbumozhi V (2020) Vulnerability of agriculture production networks and global food value chains due to natural disaster. https://www.eria.org/publications/vulnerability-of-agriculture-produ ction-networks-and-global-food-value-chains-due-to-natural-disaster/. Assessed 1 Apr 2020

Coumou D, Rahmstorf S (2012) A decade of weather extremes. Nat Clim Change 2:491-496

CRED, UNDRR (2020) The human cost of disasters: an overview of the last 20 years (2000-2019). https:// www.undrr.org/media/48008/download. Accessed 25 Oct 2020

Demeny P (1990) Population. In: Turner IIBL., Clark WC, Kates RW, Richards JF, Mathews JT, Meyer WB (eds), The earth as transformed by human action. Cambridge

DRFIP (2019) Financial protection against crises and disasters. Disaster risk finance an insurance program. global facility for disaster reduction and recovery. https://www.financialprotectionforum.org/ publication/financial-protection-against-crises-and-disasters. Assessed 9 Apr 2020

Duffin E (2020) Distribution of gross domestic product (GDP) across economic sectors in the U.S. 2017. Statistica https://www.statista.com/statistics/270001/distribution-of-gross-domestic-product-gdpacross-economic-sectors-in-the-us/. Accessed 22 Mar 2020

Geldner N, Jeglitsch H (1976) Das Inlandsprodukt nach politischen Bezirken im Jahre. WIFO Monatsberichte WIFO 49(2):54-63 (monthly reports)

Guha-Sapir D (2020) EM-DAT, CRED / UCLouvain, Brussels, Belgium. Link: https://public.emdat.be/ data. Version 2020-10-15, Accessed 25 Oct 2020

Falatehan F, Setiawan BI (2020) Economic risk characteristics of an indonesian palm oil value chain and identifying sources of uncertainty in policy making. In: Anbumozhi V et al (eds) Supply chain resilience. Springer, Singapore

FAO (2015) The impact of natural hazards and disasters on agriculture and food security and nutrition. http://www.fao.org/resilience/resources/resources-detail/en/c/280784/. Accessed 7 Nov 2020

FAO (2020) From reference levels to results reporting: REDD+ under the united nations framework convention on climate change 2020 update. http://www.fao.org/3/cb1635en/cb1635en.pdf. Accessed 17 Apr 2020

Fukushima T, Kureha M, Ozaki N et al (2002) Influences of air temperature change on leisure industries - case study on ski activities. Mitig Adapt Strat Glob Change 7:173-189. https://doi. org/10.1023/A:1022803405470

IDMC (2015) Disaster-related displacement risk: Measuring the risk and addressing its drivers. International Displacement Monitoring Centre, Geneva

ILO (2011) Unleashing rural development through productive employment and decent work: Building on 40 years of ILO work in rural areas. FOR DEBATE AND GUIDANCE. https://www.ilo.org/ public/libdoc/ilo/GB/310/GB.310_ESP_1_engl.pdf. Assessed 1 Apr 2020

ILO (2019). Sustainable tourism - a catalyst for inclusive socio-economic development and poverty reduction in rural areas. https://www.ilo.org/wcmsp5/groups/public/---ed_dialogue/---sector/docum ents/publication/wcms_601066.pdf.1 Apr 2020

ILO (2020) ILOSTAT free and open access to labour statistics. https://ilostat.ilo.org/data/. Accessed 10 April 2020

ISO (2012) ISO 22311:2012 Societal security-Video-surveillance-Export interoperability. https:// www.iso.org/standard/53467.html. Accessed 11 Sept 2020

ISO (2019) Security and resilience-business continuity management systems-requirements ISO 22301:2019 https://www.iso.org/standard/75106.html. Accessed 11 Sept 2020

Kodaira H. (2016). On the sixth industrialization. Cited in Yamaji E. (2020).

Koleski K (2017) The 13th five year plan. U.S.-China Economic and Security Review Commission. https ://www.uscc.gov/sites/default/files/Research/The\%2013th\%20Five-Year\%20Plan_Final_2.14.17_ Updated\%20\%28002\%29.pdf. Accessed 18 Mar 2020

Lock S (2020) Share of GDP created by travel and tourism worldwide 2000 to 2019. https://www.stati sta.com/statistics/1099933/travel-and-tourism-share-of-gdp/. 15 Apr 2020

Lowder SK, Skoet J, Raney T (2016) The number, size, and distribution of farms, smallholder farms, and family farms worldwide. World Dev 87:16-29

Lütz J (2013) Climate migration - preparedness informed policy opportunities identified during field research in Bolivia, Bangladesh and Maldives

Morita A (2020) 20 countries still restrict Japanese food imports 9 years after earthquake disaster. In Japan forward, 27 March 2020. https://japan-forward.com/20-countries-still-restrict-japanese-foodimports-9-years-after-earthquake-disaster/. Retrieved 10 Nov 2020

Merten J, Röll A, Guillaume T, Meijide A, Tarigan S, Agusta H, Dislich C, Dittrich C, Faust H, Gunawan D, Hein J, Hendrayanto A, Knohl Y, Kuzyakov KW, Hölscher D (2016) Water scarcity and oil palm 
expansion: social views and environmental processes. Ecol Soc 21(2):5. https://doi.org/10.5751/ ES-08214-210205

Mongabay (2018) Indonesian president signs a 3-year freeze on new oil palm licences. In: Mongabay series: indonesian palm oil, Jokowi Commitments. As of 20 Sept 2018

Munich Re (2017) Resilience (In German: Resilienz). In: Naturkatastrophen 2016 analysen, Bewertungen, Positionen. https://www.munichre.com/content/dam/munichre/global/content-pieces/docum ents/TOPICS_GEO_2016-de\%20(11).pdf. Accessed 31 May 2019

OECD (2018) Assessing the real costs of disasters. OECD Rev Risk Manag. 8 Apr 2020

OECD (2020) Trends in tourism

OECD, World Bank (2019) Fiscal resilience to natural disasters. Lessons from country experiences. OECD Publishing, Paris

Palmoilalliance (2020) Sustainable palm oil for Europe in 2019. https://palmoilalliance.eu/wp-content/ uploads/2020/09/New-Palm-IG-6.5.pdf. Accessed 9 Nov 2020

Peduzzi P (2005) Is climate change increasing the frequency of hazardous events? published in environment \& poverty times $n^{\circ} 3$. Special edition for the world conference on disaster reduction, $18-22$ Jan 2005, Kobe. UNEP/GRID-Adrenal. p 7

Plecher H (2020) Economic sector distribution of the workforce in Japan 2019. Statistics and market data on japan. Statistica. https://www.statista.com/markets/422/topic/512/japan/. Accessed $22 \mathrm{Mar}$ 2020

Plecher H (2020) Economic sector distribution of the workforce in India 2019. India - statistics \& facts. Statistica. https://www.statista.com/topics/754/india/. Accessed 22 Mar 2020

Rentschler JE (2013) Why resilience matters. The poverty impact of disasters. World Bank policy research working paper. http://documents1.worldbank.org/curated/en/613071468159301542/pdf/ WPS6699.pdf. Accessed 9 Nov 2020

Roser M (2019) Two centuries of rapid global population growth will come to an end. Our world in data. https://ourworldindata.org/world-population-growth-past-future. Accessed 3 Mar 2020

SEADRIF (2017) Financial protection in southeast Asia. Supporting the preparation and implementation of the southeast Asia disaster insurance program. https://www.financialprotectionforum.org/publi cation/financial-protection-seadrif. Assessed 9 Apr 2020

Textor C (2020) Distribution of gross domestic product and workforce across economic sectors in China. https://www.statista.com/statistics/270325/distribution-of-gross-domestic-product-gdp-acros s-economic-sectors-in-china/. Accessed 30 Mar 2020

The Economist (2016) The cost of inaction: recognising the value at risk from climate change. Econ Intell Unit

UNCCD (2017) Global land outlook. Key messages. United nations convention to combat desertification. https://knowledge.unccd.int/sites/default/files/2018-06/GLO\%20English_Key_Messages_0. pdf. Accessed 9 Nov 2020

UNDESA (2019) World population prospects 2019. https://population.un.org/wpp/Graphs/Probabilistic/ POP/TOT/900. Accessed 3 Mar 2020

UNDESA (2020) Principles and recommendations for population and housing censuses. https://unsta ts.un.org/unsd/demographic/sconcerns/densurb/densurbmethods.htm\#B. Accessed 3 Mar 2020

United Nations (2015) Taking stock of the global partnership for development mdg gap task force report. https://www.un.org/millenniumgoals/

UNWTO (2017) International rural tourism development. An Asia Pacific perspective. United Nations World Tourism Organization, Madrid

UNWTO (2019) Gastronomy tourism. The case of Japan. United Nations World Tourism Organization, Madrid

UNWTO (2019a) International tourism highlights. https://www.e-unwto.org/doi/pdf/https://doi. org/10.18111/9789284421152. Assessed 10 Apr 2019

USDA (2020) Estimate of expected harvest capacity in 2020. https://www.indexmundi.com/agricultur e/?commodity $=$ palm-oil. Assessed 9 Nov 2020

Wang T (2020) Economic loss from natural disaster events globally from 2000 to 2019. As of Jan. 24th, 2020. https://www.statista.com/statistics/510894/natural-disasters-globally-and-economic-losses/

Whitmore TM, Turner II BL, Johnson DL, Kates RW, Gottschang T (1990) Long-Term Population Change. In: Turner II BL, Clark WC, Kates RW, Richards JF, Mathews JT, Meyer WB (eds) The earth as transformed by human action. Cambridge University Press, Cambridge

Wolfert S, Lan G, Verdouw C, Bogaardt MJ (2017) Big data in smart farming-a review. Agric Syst 153:69-80 
World Bank (2020) New country classifications by income level: 2019-2020. 1 July 2019. https://blogs .worldbank.org/opendata/new-country-classifications-income-level-2019-2020. Accessed 12 Mar 2020

WTO (2020) World trade statistical review 2019. https://www.wto.org/english/res_e/statis_e/wts2020_e/ wts2020_e.pdf. Accessed 9 Nov 2020

Yamaji E (2020) Assessing the competitive advantage of public policy support for supply chain resilience. In: Anbumozhi V et al (eds) supply chain resilience. Springer, Singapore

Publisher's Note Springer Nature remains neutral with regard to jurisdictional claims in published maps and institutional affiliations. 